\title{
España en Tánger durante la Segunda Guerra Mundial: La consumación de un viejo anhelo
}

\author{
SUSANA SUEIRO
}

La cuestión de Tánger venía siendo un tema central y recurrente de la política exterior española desde los lejanos tiempos en que las grandes potencias mediterráneas se habian repartido el norte de África. A lo largo del siglo, España habia protestado en numerosas ocasiones por la humillación que suponia que este enclave, geográficamente situado dentro de la parte norte de Marruecos que los tratados le habian adjudicado, hubiera quedado sin embargo fuera de su zona de influencia. El puerto y ciudad de Tánger, asi como su hinterland o territorio circundante, se sometieron a una administración internacional, legalmente sancionada en 1923 en virtud de un Estatuto que firmaron Francia, España y Gran Bretaña, y al que posteriormente se adhirieron también Holanda, Bélgica, Suecia, Italia y Portugal ${ }^{1}$. Todos los países firmantes de aquel Estatuto participaron en los distintos órganos de la administración, pero fue Francia quien tuvo en ellos una posición hegemónica ${ }^{2}$. España, la segunda potencia en importancia, nunca soportó la preponderancia francesa y sólo por obligación aceptó una internacionalización que le irritaba profundamente y que consideraba una imposición de las otras potencias europeas. La reivindicación de un Tánger español fue constante ${ }^{3} \mathrm{y}$, mientras tanto la actitud de España fue la de obstruir el normal funcionamiento de la administración,

Sobre las vicisitudes para la firma del Estatuto de 1923 y la postura del gobierno español durante las negociaciones, vease Susana Sueiro Seoane, "El contencioso de Tánger. El Estatuto de 1923", Actas del Congreso Internacional "El Estrecho de Gibraltar», UNED, 1989, págs. 379-396.

2 Francia controlaba de hecho los resortes de la vida local. Disponia de la mayoria en la Asamblea Legislativa y, aún más importante, controlaba al menos al $70 \%$ de la población nativa a traves del Mendub, representate del Sultán, y por lo tanto representante de los intereses franceses desde el momento en que el Sultán, protegido de Francia, estaba bajo su directa influencia.

3 La campaña a favor de un Tánger español tuvo uno de sus momentos más activos en los años de la dictadura de Primo de Rivera en que, de hecho, el gobierno español, en 1926, presentó 
empeñada en demostrar que el régimen internacional era, además de injusto, totalmente impracticable e ineficaz. Las fricciones hispano-francesas a propósito del contencioso tangerino fueron habituales y Gran Bretaña, como de costumbre, adoptó el dificil papel de moderadora y conciliadora de intereses y sensibilidades encontrados.

\section{LA OCUPACIÓN ESPAÑOLA DE TÁNGER Y EL DESMANTELAMIENTO DEL RÉGIMEN INTERNACIONAL}

En junio de 1940, el régimen de Franco encontró la ocasión de oro para cumplir un viejo anhelo. Dos días después de la entrada de Italia en la guerra (el 11 de junio), cambió su posición de neutralidad por la de «no beligerancia" con el inequívoco sentido de prebeligerancia, e inmediatamente procedió a la ocupación de Tánger ${ }^{4}$. Entre las 7 y las 9 de la mañana del día 14, inminente ya el hundimiento de Francia, 4.000 soldados de las tropas moras del Marruecos español tomaron la ciudad y su zona ${ }^{5}$. $\mathrm{Ni}$ Francia, que sufría por entonces el mayor desastre de su historia, ni

oficialmente su reclamación ante las demás potencias mediterráneas. A este respecto, véase Susana SUEIRO SEOANE, "La incorporación de Tánger, una batalla perdida de la diplomacia primorriverista", Espacio, Tiempo y Forma, Serie V, no2, 1989, págs. 60-87.

${ }_{4}$ Otros trabajos que con anterioridad se han referido al tema de la ocupación española en Tánger son: Charles R. y Carolyn J. Halstead: “Aborted Imperialism: Spain's Occupation of Tangier 1940-1945", Iberian Studies, vol. II, № 2, otoño de 1978. Antonio Marouina Barrios, "de las pretensiones al naufragio (1939-1956)", Historia 16. Extra IX (abril 1979): España en África, págs. 49-55. Miguel Hernando de Larramendi, "Tánger durante la ocupación española, 19401945", Actas del Congreso Internacional "El Estrecho de Gibraltar", Madrid, 1988, tomo III, págs. $571-582$.

5 Desde el mes de abril venían circulando rumores sobre un posible movimiento español sobre Tánger; a Melilla llegaron tropas desde la Península y se estacionaron en las fronteras del protectorado. Varios miles de prisioneros integrados en batallones de trabajo fueron enviados también. Para los españoles, llevar tropas desde el área de Tetuán hasta Tánger no revestia ninguna dificultad ni requeria especiales preparativos. El problema para España era que Francia con toda seguridad respondería a esta acción con un avance desde el protectorado francés hasta ocupar Tetuán, una maniobra que tampoco suponía un gran esfuerzo para Rabat. Los diplomáticos británicos no creian que España se decidiese a llevar a cabo acción alguna sobre Tánger debido a la amenaza de la respuesta militar francesa, y tendieron a interpretar las maniobras militares como una estrategia dictada por alemanes e italianos para hacer creer a Francia que España preparaba una ofensiva inminente, al objeto de que retuviera en el Marruecos francés tropas que de otro modo habria podido llevar a otros frentes. Al cónsul británico tampoco le parecía descabellado que el General Ponte, Comandante en jefe de las tropas en el Marruecos español, fuese sincero cuando le aseguraba, ante sus insistentes preguntas, que esas maniobras se debian a la necesidad de estar preparados para reprimir posibles disturbios en España, dada la terrible situación económica que alli reinaba. Véase, el cónsul británico en Tánger, A. GASCOIGNE, a ViscounT Halifax, Secretario de Estado para Asuntos Exteriores. Tánger, 18 de abril, 25 de abril, $1^{\text {o }}$ de mayo... de 1940. PRO, FO 371/24446. 
Gran Bretaña, muy ocupada tras el descalabro de Dunkerque, hicieron nada. Tánger constituía desde luego uno de los principales intereses de Gran Bretaña en la zona del Estrecho, pero en aquel momento había otros intereses vitales que se anteponían, en concreto lograr que España no entrara en la guerra a favor del Eje, de modo que el Foreign Office adoptó una política de apaciguamiento y entendimiento con el gobierno franquista. Con respecto a Tánger esto significaba aceptar la nueva situación, y tratar únicamente de conseguir que se garantizasen los derechos e intereses de la colonia británica, que por entonces ascendía a unas 1.700 personas $^{6}$.

De este modo, la ocupación española se realizó de forma tranquila y pacífica, sin incidentes destacables. Hitler felicitó a Franco por su acción. Los italianos mandaron también una nota de felicitación, aunque menos entusiasta ${ }^{7}$. Al cónsul británico le parecía muy al estilo alemán la entrada triunfal que hicieron los españoles en la ciudad, mediante una exhibición pública con desfiles militares por las calles y banderas nacionales ondeando en todos los edificios españoles ${ }^{8}$. El administrador francés, uno de los principales funcionarios de la zona, fue rápidamente sustituido por un español. No obstante, las nuevas autoridades aseguraron que la ocupación tenía un carácter provisional cuyo único objeto era garantizar el orden y la neutralidad de la ciudad ${ }^{9}$. España-se dijo-prestaba así un gran servicio a Europa, aunque también se aludió a que había sido necesario actuar para suprimir las peligrosas actividades de los «elementos rojos" de Tánger ${ }^{10}$.

6 Incluidos en esta cifra los evacuados de Gibraltar y algunos otros procedentes del sur de Francia y del Marruecos trancés. Los residentes permanentes eran unos 900 en 1940 aunque, en los años siguientes, más de 200 abandonaron Tánger. La población de Tánger era por entonces de unos 61.000 habitantes, 18.000 europeos de diversas nacionalidades, 7.000 judios y 36.000 musulmanes nativos.

Según el cónsul británico, en realidad a los italianos no les habia hecho ninguna gracia la ocupación española, y mucho menos les haria la anulación de la administración internacional en los meses siguientes. Según contaba Serraño Suñer en 1945, en una entrevista concedida a un periodista francés, Italia habia mandado una cortés aunque escueta nota de felicitación. Véase, PRO, FO 371/49663

8 Cónsul británico en Tánger a Lord Halifax, 14 de junio de 1940. PRO, FO $371 / 24452$

9 El entonces Alto Comisario, General Asensio, justificó la ocupación en una nota enviada a los representantes de las distintas potencias en Tánger, asegurando que España la habia llevado a cabo en previsión de graves altercados entre las distintas colonias europeas, más aún cuando Italia acababa de entrar en la guerra. Sin embargo, el cónsul británico informaba a su gobierno que nada de esto era cierto y que, tras la entrada de Italia en la guerra, la situación de Tánger habia permanecido tranquila.

${ }_{10}$ La colonia española -unas 14.000 personas en 1940 - había sido mayoritariamente republicana durante la guerra civil. Dejando aparte al Ejército estacionado en Tánger, los españoles de esta ciudad estaban mejor dispuestos hacia los aliados que el pueblo español en general porque muchos republicanos buscaron refugio allí amparándose en la administración internacional. 
Desde luego, para nadie era un secreto que se trataba tan sólo de excusas para cumplir una aspiración largamente soñada. En enero de 1941 Serrano Suñer, Ministro de Asuntos Exteriores desde octubre de 1940, hizo unas declaraciones sobre el tema tangerino a la revista del SEU, Haz, que eran un típico ejemplo del discurso reivindicativo español desde hacía tres décadas ${ }^{11}$. No puede olvidarse que muchos de los que gobernaban el país, empezando por el propio Franco, eran militares africanistas que habian hecho sus carreras en Marruecos y, como señalaba el embajador británico, Samuel Hoare, "para ellos las cuestiones marroquies son las más importantes del mundo". El ex ministro Hoare, enviado a Madrid "en misión especial" en mayo de 1940, estaba realmente impresionado por el enorme peso que tenía para el gobierno todo lo relativo al protectorado marroqui, y en general al norte de África, algo que - según reconocia - ignoraba por completo antes de su llegada, y hacia notar que gran número de sus informes desde que estaba en Madrid versaban sobre este asunto:

“En mis visitas casi diarias al Ministro de Asuntos Exteriores -aseguraba a las pocas semanas de establecerse en Madrid - la conversación acaba siempre desembocando antes o después en el tema de Marruecos» ${ }^{12}$.

De hecho, al tiempo que procedía a la ocupación de Tánger, el gobierno español se preparaba para cumplir un objetivo más ambicioso: la ocupación del Marruecos francés, que era su gran aspiración expansionista en el norte de África. Tras el hundimiento de Francia, se pensó que cundiría el caos en la zona francesa de Marruecos y, en la confusión, España intervendría, de nuevo con la excusa de restablecer el orden. Sin embargo, el deseado colapso no se produjo ya que las autoridades de Rabat decidieron obedecer los términos del armisticio y aceptar la autoridad de Vichy. A pesar de los preparativos militares que se habían realizado, el gobierno de Franco no se atrevió a llevar a cabo una ocupación por la fuerza ante la evidencia de que los franceses, que habian reforzado con tropas la frontera, se aprestaban a resistir el ataque. Las conversaciones

\footnotetext{
11 También Franco, en una conversación con el embajador británico a comienzos de febrero, utilizó los viejos argumentos de siempre para reivindicar Tánger para España: Tánger era geográficamente parte integrante de la zona española y no podía ser desgajada de ella; los Tratados internacionales habian constituido una afrenta para España al consagrar un régimen internacional para Tánger totalmente artificial, etc., etc. Véase, Sir S. HOARE a Foreign Office, 8 de febrero de 1941. PRO, FO $371 / 26893$.

1219 de septiembre de 1940. El Ministro de Exteriores era entonces Juan BEIGBEDER, otro destacado africanista.
} 
que a continuación se mantuvieron con Alemania, Italia y Vichy para cumplir este ansiado objetivo por la vía de la negociación obtuvieron un resultado totalmente desalentador ${ }^{13}$. Como a estas alturas es ya archisabido, la escasa disposición de Hitler a satisfacer las reivindicaciones coloniales de España fue el factor decisivo para que Franco se abstuviera de entrar de inmediato en la guerra al lado del Eje, como había sido su intención ${ }^{14}$. Los diversos intentos de llegar a un "arreglo" con Vichy por la vía diplomática tampoco resultaron fructíferos ${ }^{15}$.

13 Los españoles llevaban décadas denunciando la injusticia del reparto marroqui. Desde principios de siglo, cada nuevo tratado internacional firmado por España habia supuesto la reducción de la superficie que se le atribuia en Marruecos, que finalmente habia quedado reducida a los pobres y agrestes territorios del Rif y Yebala, mientras Francia se quedaba con todas las ricas y fértiles llanuras.

En los años de la Segunda Guerra Mundial, hubo reclamaciones claramente imperialistas, defendidas por los falangistas, que aspiraban a anexionarse todo el Marruecos francés, y que fueron las que se presentaron a Alemania como contrapartida para entrar en la guerra. Sin embargo, ante la falta de respuesta de Hitler a tamaña cesión, los españoles establecieron contactos directos con Vichy, e incluso con los británicos, para que les reconociesen al menos una rectificación de fronteras entre las dos zonas de Marruecos que viniese a corregir lo que en España se consideraba una clara injusticia. Esta tendencia, a la que conviene más el calificativo de "irredentista" que el de "imperialista" ya que no era sino la continuación de la tradición reivindicativa española de las pasadas décadas, muy anterior por tanto a la formulación de la idea fascista del imperio, se basaba en la necesidad de "recuperar" unos territorios que España sostenia que le pertenecian por derecho

Había quienes sostenian que España no debia consentir nada que no fuera el reconocimiento del primer trazado de la frontera, esto es, el que figuraba en el famoso tratado "nonato" de 1902

Más apoyatura jurídica tenía, sin embargo, la reclamación de llevar la frontera al limite previsto en la declaración franco-española de 1904, lo que suponia incluir la fértil cuenca del río Uarga, muy apta para la agricultura, dentro de la zona española.

La demanda más modesta se refería a un cumplimiento "correcto y desapasionado" del vigente tratado hispano-francés de 1912, lo que para los españoles significaba incluir dentro de su zona la fértil región de Beni Zerual, que venia siendo objeto de un largo y ya histórico contencioso entre ambos países.

Sobre las reclamaciones territoriales españolas en Marruecos en los años de la Segunda Guerra Mundial en sus múltiples versiones, véase, Susana SuIERo SEOANE, "Sueños de Imperio: Las pretensiones territoriales españolas en Marruecos y la diplomacia británica durante la Segunda Guerra Mundial», en Tusell, Sueiro, Marín y Casanova (eds.), El régimen de Franco. Politica y Relaciones exteriores, tomo II, Madrid, 1993, págs. 299-308.

14 Hitler prefirió no comprometer sus relaciones con Vichy, por lo que no mostró ningún interés por satisfacer las demandas territoriales concretas que España reclamó a cambio de su beligerancia. España únicamente obtuvo de Alemania una vaga perspectiva de participación en el Nuevo Orden europeo si se producia la victoria del Eje, algo en lo que Franco estuvo convencido hasta prácticamente el final de la contienda.

15 El régimen franquista fracasó en sus intentos de convencer a Pétain de que aceptase una ocupación española del Marruecos francés como forma de garantizar el orden. La negativa tajante correspondió al general Noguès, comandante militar en Argelia, que no quiso ni oír hablar del asunto para irritación de las autoridades españolas de Marruecos, que comentaron que «no era ésta la actitud lógica de una potencia derrotada". El cónsul británico en Tetuán, al dar cuenta de los intercambios de visitas en el transcurso de 1941 entre el Alto Comisario español y el general Noguès, señalaba el mal humor de los españoles ante la "terca" actitud de los franceses, que no mostraban el grado de humildad que seria de esperar y se negaban a reconocer que su derrota les habia privado de la autoridad y el respeto que antes tenian como potencia colonial. Véase, Annual Report on events in the Spanish Protectorate of Morocco for the year 1941, PRO, FO 371/31240. 
Lo cierto es que el gobierno de Franco había formulado sus ambiciones imperiales de forma tan explícita ${ }^{16}$ que no extrañó a nadie que no cumpliera sus promesas de limitarse a garantizar el orden en Tánger. «Hordas de funcionarios sin afeitar" procedentes del protectorado español -aseguraba el cónsul británico- desembarcaron en la ciudad internacional para hacerse cargo de los distintos departamentos ${ }^{17}$. Eran miembros de Falange que no tenían ninguna experiencia sobre cómo tratar una zona con tantos intereses extranjeros implicados. Lo primero que hicieron al llegar fue deshacerse de los archivos existentes, en parte quemados y en parte trasladados en camiones a un almacén en las afueras de la ciudad. "No queremos saber nada de los métodos de la administración internacional», le dijo uno de los nuevos funcionarios al cónsul británico. "Vamos a empezar de cero y a administrar esta ciudad a la española». Pero el intento de suprimir de un plumazo la administración internacional originó tal confusión y caos administrativo que las nuevas autoridades tuvieron que dar orden de recuperar los documentos y expedientes que previamente habian mandado arrinconar. Las autoridades españolas, no obstante, no renunciaron a su primordial objetivo de desmantelar el régimen internacional, si bien decidieron optar por la vía gradual.

De momento, se aplicaron a la tarea de hacer que el aspecto y la «atmósfera" de Tánger fueran los de cualquier ciudad española. Se dictaron normas de tráfico idénticas a las que regian en España; se ordenó a los comerciantes que utilizaran únicamente el español para sus anuncios y letreros; se renovó la circulación de la peseta, suspendida en diciembre de 1936. Incluso las playas adquirieron un aspecto hispánico, ya que se prohibió tanto a hombres como a mujeres exhibir modelos de bañador que no fueran de lo más recatado. Para el cónsul británico esta norma del bañador "victoriano" era una prueba más de "la estupidez y el desconocimiento de la situación por parte de los falangistas", que no parecían tener en absoluto en cuenta que la economía de Tánger residia en su industria turística, y que la prosperidad de la ciudad dependia en gran parte en los atractivos de una vida placentera para sus residentes. En efecto, antes de la ocupación española, Tánger era un paraíso turistico donde europeos

16 Desde antes de que se produjese la ocupación de Tánger, la prensa falangista - Arriba fundamentalmente - venia insistiendo en la necesidad de refundar un Imperio; desde el punto de vista territorial era fundamentalmente en tierras africanas donde este Imperio podia realizarse, si bien hubo también alusiones a la necesidad de anexionar Portugal. En los años 40, se publicaron multitud de libros, folletos y artículos de prensa que hablaban de este tema. Una formulación explícita del imperialismo falangista está contenida en el famoso libro de José $\mathrm{M}^{a}$ de Areilza y Fernando $\mathrm{M}^{\mathrm{a}}$ Castiella, Reivindicaciones de España, publicado en 1941.

17 Véase, Annual Report. Tangier Zone, 1941. PRO, FO 371/31261. 
millonarios, escapando del rigor de los impuestos y del clima del norte de Europa, gastaban grandes sumas de dinero viviendo una grata existencia de ocio y lujo. Una próspera y cosmopolita ciudad que atraía a gran número de bañistas, turistas, pensionistas y rentistas, dedicados al relajo y la diversión.

Por fin, en noviembre, los españoles dieron el golpe decisivo. El día 3, de forma unilateral y sin previa consulta a las potencias signatarias del Estatuto de 1923, procedieron a abolir la mayor parte de los órganos de la administración internacional, despidiendo de sus puestos a los funcionarios extranjeros. La noticia apareció al día siguiente en los lugares más importantes de la ciudad, así como en el periódico español, España. El General Antonio Yuste, jefe de las tropas de ocupación, fue nombrado acto seguido "gobernador" de Tánger, encargándose personalmente de dirigir la maquinaria administrativa. Al cónsul británico, esta concentración de poderes le llenaba de inquietud por lo que a la eficacia de la gestión se refería, máxime cuando el General en cuestión tenía una total inexperiencia y desconocimiento de cuestiones administrativas civiles. El 13 de noviembre, el Boletín Oficial del Estado publicaba el decreto de incorporación de Tánger al Protectorado español de Marruecos.

En los meses siguientes, fueron eliminándose las pocas instituciones de la antigua administración que aún quedaban en vigor; paso a paso, las autoridades españolas se dedicaron a un sistemático ataque y destrucción de los intereses franceses, apoderándose de los organismos antes controlados por Francia, como por ejemplo la importante administración de aduanas. Una de las actuaciones más significativas en este sentido fue, en marzo de 1941, la expulsión del Mendub - el representante del Sultán- que era uno de los principales puntales de la influencia francesa. Los españoles presionaron sin éxito a las autoridades de Vichy para que persuadieran al Sultán de que lo reclamara y finalmente recurrieron a la fuerza: obligaron al Jalifa de la Zona española a emitir un decreto expulsando al Mendub y nombrando en su lugar a un Pachá que estaría bajo las órdenes del Jalifa y no del Sultán. El tenaz Mendub tuvo que ser desalojado a punta de pistola.

\section{LA POLITICA PRO-EJE DE LAS AUTORIDADES ESPAÑOLAS}

Desde que Tánger fue tomada por los españoles comenzó a respirarse en el enclave un ambiente totalmente germanófilo. Las autoridades españolas cedieron a Alemania la Residencia del Mendub expulsado, para que pudiese instalar alli su Consulado general. Había sido ésta la sede de la Legación alemana antes de la Gran Guerra, pero en virtud del tratado de 
Versalles había pasado a ser propiedad del gobierno marroquí ${ }^{18}$. La ceremonia de cesión se llevó a cabo en marzo de 1941 con toda solemnidad, incluyendo desfiles, disparo de salvas, banquetes, discursos y demás actos públicos en el centro de la ciudad, todo lo cual le parecía al cónsul inglés "provocador, carente de tacto, y en general intolerable tratándose de representantes de un país que, aunque admite no ser neutral, al menos dice ser «no beligerante». El Alto Comisario español en Tetuán, General Asensio - germanófilo convencido, al igual que el secretario general de la Alta Comisaría, García Figueras - pronunció exaltadas palabras señalando que la restitución a Alemania del edificio que le había sido arrebatado era uno de los primeros actos que España realizaba en Tánger desde que la zona había sido incorporada al Marruecos español, y que era expresión de «la calurosa amistad que todos los españoles sentían por quienes habian derramado su sangre por España en defensa del progreso y la civilización». A continuación se izó la bandera alemana en nombre del Führer, mientras una veintena de moros convenientemente adiestrados animaban el acto haciendo el saludo nazi ${ }^{19}$.

El Consulado se convirtió en el principal centro de espionaje y propaganda política del Reich en Tánger. Además del cónsul, Herbert Noehring, el principal agente alemán del enclave era el vicecónsul, Goeritz, que hablaba perfectamente español por haberse criado en Sudamérica ${ }^{20}$. Una de las

18 Privada de derechos desde el final de la guerra del 14, Alemania carecia de representación oficial y era el representante holandés quien estaba al cargo de los intereses alemanes en Tánger.

19 No obstante, según los diplomáticos británicos, habia quedado un tanto deslucido ver cómo luego estos indigenas se amontonaban a la entrada de la Residencia abalanzándose para cobrar los cinco francos marroquies con que las autoridades españolas premiaron a cada uno de ellos.

20 Aparte de Tánger, en el Marruecos español, Tetuán era el principal centro de la acción alemana. Todos los miembros del Consulado eran agentes, empezando por el cónsul, Richter, y sobre todo el vicecónsul, Braun, que era quien trataba personalmente con los agentes de los servicios especiales. Por lo que respecta a la penetración alemana en el mundo indigena, tenia un destacado papel un alemán llamado Langenheim que llevaba largo tiempo en Marruecos, conocia profundamente el pais y tenía, además, contacto directo con el gobierno de Berlin ya que uno de sus hijos, Oswald, pertenecia al gabinete de Von Ribbentrop. Pero habia otros muchos agentes importantes, como el jefe local del partido nazi, llamado Zobel; el director local de la compañia hispano-alemana HISMA, llamado Mawick, y muchos otros. En Ceuta, de nuevo los agentes más activos eran el agente consular, Hoffmann; el director local de HISMA, Hermann Paege; y representantes comerciales como Uirich o Kurt Meyer. Los directores de la casa comercial Renschausen, con sucursales en Larache, Tetuán. Tánger, Casablanca y Rabat, actuaban también como agentes. En Melilla, el personaje más activo era Walter Kraemer. Véase el largo y detallado informe titulado L'action allemande au Maroc Espagnol. PRO, FO 371/24447. Por lo que respecta a HISMA ("Sociedad Hispano-Marroqui de Transportes"), esta sociedad, que desde su constitución en julio de 1936 habia monopolizado prácticamente el comercio con el Marruecos español, se había disuelto oficialmente en septiembre de 1940 a causa 
misiones de los agentes era vigilar los movimientos de los barcos aliados que cruzaban el Estrecho. Apostados las 24 horas del día en los diversos puestos de observación distribuidos por la costa española, Tánger, el Marruecos español y las plazas de Ceuta y Melilla, transmitian la información en clave cumpliendo su cometido sin ningún tipo de trabas ${ }^{21}$. A lo largo de toda la costa africana del Estrecho se llevaron a cabo obras de fortificación directamente planificadas y supervisadas por los alemanes, incluyendo la zona de Tánger, a pesar del compromiso español de no hacerlo. Por lo demás eran muchos los funcionarios españoles que estaban a sueldo de los alemanes ${ }^{22}$.

La actividad del nuevo Consulado se notó muy pronto en la vida de la ciudad. Sólo tres dias después de la llegada del cónsul, las autoridaes locales españolas impusieron la censura de prensa. Al cónsul británico no le cabía duda de que había sido a instigación alemana, para dificultar la difusión de la propaganda británica, y en concreto de la Tanger Gazette, un diario vespertino que en el último año venía publicando el agregado de prensa del Consulado británico. Este diario, el único órgano portavoz de la causa aliada en todo Marruecos ${ }^{23}$, sufrió la severa acción de los censores

del bloqueo aliado, pero en realidad siguió funcionando y sus representantes tuvieron un relevante papel como agentes.

21 Ante las protestas británicas sobre las actividades de espionaje y sabotaje de los agentes enemigos, $y$ ante indicaciones concretas de que en determinadas viviendas habitadas por alemanes se habian instalado radares y otros sofisticados aparatos para detectar la posición de los barcos aliados, las autoridades españolas no tuvieron más remedio que llevar a cabo algún registro que, por supuesto, resultó infructuoso ya que, según el cónsul británico, no existia ni el más ligero asomo de duda de que los elementos alemanes habian sido avisados previamente del registro que iba a efectuarse.

22 Una residente británica en Tánger, Jessie Greer, cuya información era muy estimada en el Foreign Office, aseguraba: "No se imagina lo corrompidos que están actualmente en Marruecos tanto los franceses como los españoles. La corrupción es absolutamente general entre los funcionarios, desde el más alto al más bajo y se sorprenderia Ud. de las pequeñas cantidades que aceptan. Su única excusa es que su sueldo es miserable y que tienen que vivir. Los alemanes pueden hacer lo que quieran con los franceses, pero tienen que tener más cuidado con los españoles, que son muy orgullosos. No obstante, el dinero manda, y parece que los alemanes tienen mucho y lo gastan generosamente" (Tánger, 18 de agosto de 1941. PRO, FO 3721/26960).

Los británicos también pagaban a algunos funcionarios de la zona, pero éstos, a diferencia de lo que ocurría con los que estaban a sueldo de los alemanes, se arriesgaban a ser detenidos. En septiembre de 1941, por ejemplo, se supo por el coronel de Miguel, principal ayudante de campo de la Alta Comisaria, habia sido arrestado, probablemente a instigación de Garcia Figueras, acusado de estar en contacto con agentes británicos en Tánger y de haber recibido de ellos un sustancioso cheque. Otros funcionarios de Tanger fueron investigados bajo sospecha de estar también pagados por Gran Bretaña. Véase, Gascoigne a Foreign Office, 15 de septiembre de 1941 PRO, FO 371/26960.

23 Habia dos ediciones diarias, en francés y español, y otra bisemanal, en inglés. A principios de 1941 se vendian unos 5.000 ejemplares al dia en Tánger y zonas española y francesa de Marruecos 
españoles, por lo general rabiosamente germanófilos, que no sólo realizaban continuas mutilaciones impidiendo la publicación de noticias desfavorables para Alemania, sino que dilataban al máximo su labor censora para retrasar la hora de salida del diario y reducir de este modo su venta ${ }^{24}$. Mientras tanto, los órganos italiano (Vedetta di Tangeri), francés (Dépêche Marocaine) y español (España), circulaban con entera libertad y publicaban continuamente artículos ofensivos para Gran Bretaña. Igual que en la zona española de Marruecos, Tánger se llenó de propagandistas alemanes e italianos que distribuian libremente sus periódicos y revistas en tiendas y demás establecimientos. El Consulado británico estaba convencido de que las propias autoridades españolas no controlaban las actividades de estos agentes, en cuyas manos estaba toda la propaganda pro-Eje en la zona ${ }^{25}$. La propaganda alemana era también muy intensa entre la población marroquí, a la que atraian con promesas de una futura independencia. De hecho, los líderes de los principales partidos nacionalistas recibian importantes sumas de dinero de los alemanes ${ }^{26}$.

Mientras la distribución de la propaganda del Eje se hacía sin cortapisas, la propaganda británica tendió a ser discreta, distribuida por canales privados e incluso clandestinos, dados los obstáculos impuestos por las

24 Por lo demás, en el Marruecos español la Tangier Gazette solo podia adquirirse, como el resto de los periódicos y boletines de noticias británicos, en la oficina de correos británica de Tetuán. La policía secreta española, apostada en las inmediaciones, perseguia a todo individuo que salia de la oficina de correos y si llevaba la gaceta, se la confiscaban.

25 Véase, comentario de Williams, 3 de diciembre de 1941. PRO, FO/371/26968. La Oficina de Prensa y Propaganda de Tetuán fue el principal canal utilizado por los alemanes para difundir su propaganda en la zona. Una gran pizarra exhibida en la sede de esta oficina, situada en la calle principal de la ciudad, daba diaria noticia del curso de la guerra desde una óptica absolutamente pro-alemana. Además, el periódico más leído en la zona española, España, con una tirada de 50.000 ejemplares al día frente a los 1.000 de la edición española de la Tangier Gazette, era totalmente germanófilo ya que estaba subsidiado por los alemanes con importantes sumas de dinero, frente a las discretas 25 libras que el gobierno británico gastaba a la semana en un subsidio para su órgano propagandístico. El resto de los periódicos de la zona española, como El Telegrama del Rif, de Melilla, o El Faro, de Ceuta, eran también totalmente germanófilos. Por lo que respecta a la propaganda radiofónica, en todas las ciudades del protectorado habia altavoces, situados en los lugares más concurridos, que varias veces al día bombardeaban a la población con propaganda alemana y falangista amplificada.

26 El más pro-germánico era Abdel Kaleq Torres, dirigente del Partido de la Reforma Nacionalista, cuyo periódico, Al Hurriya, estaba directamente al dictado de los alemanes. El lider del partido rival, Mekki el Nasiri, que dirigia el Partido de la Unidad Marroqui, mostraba también una tendencia pro-Eje en su órgano de opinión, si bien era más moderado e incluso se disculpaba ante los británicos asegurando que carecia de libertad para publicar lo que queria, por estar sometido a una fuerte presión de los alemanes. Los británicos, por su parte, trataban de inculcar entre los musulmanes la idea de que el racismo del movimiento nazi no era sólo antisemita sino también anti-islámico. 
autoridades españolas ${ }^{27}$, que prohibian todo lo que pudiese ofender las susceptibilidades alemanas. Folletos y panfletos se pasaban de mano en mano, o bien eran enviados por correo. El servicio de propaganda británica para todo Marruecos estaba en Tánger, a cargo del agregado de prensa del Consulado británico, el coronel Ellis, que trató de introducir un cierto grado de eficacia en su tarea para contrarrestar la frenética actividad propagandística alemana desatada tras la instalación del Consulado general alemán. Poco a poco, y a pesar de las dificultades y los escasos medios con que contaba ${ }^{28}$, logró organizar cierta labor de prensa y propaganda y, tras la entrada de EE.UU. en la guerra, estableció una estrecha relación con su colega americano ${ }^{29}$.

Toda la política propagandística de Gran Bretaña en Tánger y en el Marruecos español estuvo guiada por la preocupación de mantener las mejores relaciones posibles con las autoridades españolas. Es verdad que, amparándose en varios tratados hispano-marroquíes suscritos en el pasado, que garantizaban la inmunidad de los envios y paquetes dirigidos al Consulado a efectos de inspección aduanera, pudo entrar durante la guerra gran cantidad de propaganda británica en Tánger. Pero los británicos decidieron no destinar a esta labor grandes sumas, y nunca tuvieron la pretensión de arrebatar a los alemanes la iniciativa. Sólo cuando

27 De forma intermitente, las autoridades españolas ponian trabas para la libre exhibición de material propagandístico británico en tiendas, bancos y demás instituciones británicas de Tánger. En cuanto al Marruecos español, Gascoigne contaba al FO cómo, en todas las ciudades, los alemanes se servian de niños que de forma indiscriminada introducian la propaganda por debajo de las puertas de las casas, algo que en absoluto les estaria permitido a los ingleses. Lo unico que ellos podian hacer era enviar sus circulares por correo a personas seleccionadas, como notables y oficiales marroquies. Véase, 21 de mayo de 1942. PRO, FO/371/31202.

28 Las quejas de Ellis en relación con el material que le enviaba el Instituto Británico, sin ningún valor para los tiempos que corrian, da idea de los pobres medios con que contaba: "La población extranjera en esta parte del mundo -decia en uno de sus informes, no sin cierta ironiano siente ningún interés por la arquitectura de Inglaterra, o por lo que está pasando en los colegios y Universidades; tampoco tiene utilidad práctica enviar largos artículos sobre to que están haciendo las estrellas del mundo del teatro, o los empresarios de la City londinense. Lo que piden son noticias de actualidad sobre el desarrollo de la guerra. Por ejemplo, los comentarios sobre la batalla de Libia no son de ningún valor una vez que los alemanes han reocupado Libia". "En fin, lo que interesa aqui -insiste- son fotografias, todo tipo de material gráfico, y también cualquier comentario sobre la opinión pública americana --tanto de América del Norte como de Sudamérica- a propósito de la guerra" (Véase, PRO, FO/371/26968). En el Foreign Office, Williams apuntó en el informe de Ellis: "es realmente asombroso que después de dos años de guerra el Ministerio de Información y el Instituto Británico manden semejante basura" Véase, comentario a mano de Williams, 10 de julio de 1941. PRO, FO/371/26968).

29 La colaboración tuvo como un de sus frutos la puesta en circulación en 1942 del Journal de Tánger, un periódico semanal, fundamentalmente destinado al Marruecos francés y que poco a poco fue adquiriendo una orientación proamericana en un proceso muy lento y gradual. 
los agentes alemanes acometieron una activa labor propagandística, los británicos trataron de hacer lo posible por igualar el volumen de la propaganda enemiga contraatacando con la misma cantidad y el mismo tipo de propaganda ${ }^{30}$. Pero, ante las autoridades españolas, siempre pudieron esgrimir el argumento de que lo habían hecho "después». Aún así, y a pesar de que los alemanes arrojaban panfletos desde sus aviones dirigidos a la población indígena, el Foreign Office mostraba sus escrúpulos a seguir los mismos pasos:

«Debemos tener cuidado y no arrojar panfletos en el Marruecos español ya que ofendería al gobierno español y podría tener repercusiones desfavorables» ${ }^{31}$.

A pesar de que la diplomacia británica recurrió a toda clase de miramientos hacia las autoridades españolas de Tánger y Marruecos ${ }^{32}$, no

30 Si los alemanes hacian un pase de una pelicula contando las excelencias de su máquina de guerra, los ingleses pedian al Ministerio de Información que enviase alguna película patriótica probritánica para contrarrestarla. Si los alemanes distribuian material ofensivo, los británicos respondian con material del mismo tipo. Si los alemanes comenzaban a distribuir un boletín de noticias en árabe para la población nativa, los británicos a continuación hacian lo propio.

Tanto los alemanes como los británicos distribuian un boletín sémanal en árabe. La propaganda alemana entre los marroquíes se dirigia sobre todo a convencerles de su superioridad bélica. En cambio, la británica hacia hincapié en los recursos económicos de los aliados y para ello se distribuian periódicamente cajas con té, margarina, chocolate y frutos secos exportadas desde Inglaterra con la leyenda “Inglaterra cumple sus promesas». Véase PRO, FO 371/31277.

31 Roberts, 21 de abril de 1941. PRO, FO, 371/26893.

32 Otra de las vertientes de su politica de apaciguamiento consistió en contemplar la posibilidad de respaldar las reclamaciones españolas en el Marruecos francés. Hubo conversaciones sobre el particular con varios militares partidarios de mantener a España fuera de la guerra e incluso el general Aranda entregó al agregado militar inglés un memorandum sobre sus demandas en el Marruecos francés. Tras estudiar detenidamente el tema, el Foreign Office reconoció que habia argumentos razonables para sostener el trazado de la frontera previsto en el tratado de 1904. que incluía el valle del Jarga en la zona española. No obastante, a pesar de los requerimientos de Hoare para que Gran Bretaña respaldara la cesión de territorio del Marruecos francés a favor de España, se consideró preferible no dar un apoyo explícito ya que los franceses to considerarian una traición. La conclusión, en cada ocasión en que Hoare planteó la cuestión -y fueron muchas- fue que las relaciones con Vichy y con las autoridades francesas de Marruecos eran más importantes que cualquier cosa que pudiera pasar en España. Los britanicos, entrentados al mismo dilema que los alemanes - aceptar las reclamaciones españolas o mantener sus relaciones con los franceses- decidieron, igual que éstos, que les convenia más apoyar los intereses de Francia lo que, en Marruecos, significaba no satisfacer los de España. En cualquier caso, ef Foreign Office autorizó a Hoare a expresar en Madrid que Gran Bretaña veía con simpatia sus demandas, sin especificar más. Sobre las reclamaciones marroquíes de España en los años 40 y la actitud británica, véase Susana Sueiro Seoane, "Sueños de Imperio: las pretensiones territoriales españolas en Marruecos y la diplomacia británica durante la Segunda Guerra Mundial», en Tusell, Sueiro, Marín y Casanova (eds.): El régimen de Franco. Política y relaciones exteriores. Tomo II. Madrid, UNED, 1993, págs. 299-319. 
faltaron momentos muy tensos en que los británicos realmente hubieron de hacer "de tripas corazón". En febrero de 1942, en un momento en que Gran Bretaña sufría importantes reveses en los escenarios bélicos, se produjo un acto de sabotaje. Una bomba estalló en el puerto de Tánger haciendo saltar por los aires las valijas diplomáticas británicas que acababan de ser descargadas del barco que todas las semanas hacía la ruta Gibraltar-Tánger. Hubo once muertos y casi cuarenta heridos, muchos de ellos británicos. Sin que prácticamente se hubiesen iniciado las investigaciones para esclarecer el suceso, el entonces ministro de Exteriores, Serrano Suñer, publicó en el diario España un comunicado asegurando que la bomba procedía de Gibraltar y que había sido colocada por los británicos en sus valijas, probablemente para cometer algún atentado en Tánger. Esta acusación directa provocó en los días siguientes gravísimos ataques antibritánicos en Tánger, fundamentalmente dirigidos contra el Consulado general, la oficina de correos y otros establecimientos públicos y privados de propiedad británica. Para el cónsul lo más desagradable no era la injusta acusación —el Consulado tenía la seguridad de que la bomba no iba en el barco- sino el que los disturbios antibritánicos se hubiesen producido ante la total pasividad cuando no complicidad de las autoridades españolas. Mientras los asaltantes - sobre todo nativos y españoles-destruian las propiedades británicas, la policia y el personal militar al servicio del General Uriarte contemplaban la escena cruzados de brazos y con obvio regocijo, y en algún caso incluso dando instrucciones de cómo debia realizarse el asalto ${ }^{33}$. El cónsul pensaba que para recuperar el prestigio británico en la ciudad había que hacer algo más que expresar las consabidas protestas verbales, pero el Foreign Office consideró que lo más prudente era tratar de echar tierra al asunto e intentar que se olvidase cuanto antes; ni siquiera presionó en exceso para exigir una indemnización por los importantes destrozos causados que, por supuesto, los españoles nunca pagaron. Además y para no provocar nuevos incidentes, el Foreign Office instruyó al servicio de propaganda para que extremase la cautela y no respondiese a las provocaciones de la propaganda alemana. Los boletines de noticias, fotografías y demás publicidad británica dejaron de exhibirse en público ${ }^{34}$.

\footnotetext{
3.3 Véase, por ejemplo, consulado general de Tánger, 9 de febrero de 1942. PRO, FO, $371 / 31256$.

34 En los lugares donde estaban a la venta fueron guardados en carpetas de modo que sólo aquellos que lo solicitaban podian verlos. Véase, Ellis a FO, 19 de abril de 1942. PRO, FO/371/31202.
} 
Como vemos, los diplomáticos británicos en Tánger y Tetuán soportaron provocaciones y ofensas sin tomar ninguna represalia; muy al contrario, se abstuvieron de toda acción que pudiera resultar molesta para las autoridades españolas, empeñados en conseguir unas relaciones fluidas e incluso cordiales. En relación con Tánger, la primera muestra de esta política de contemporización fue su reconocimiento de hecho de la ocupación española, aceptando asistir a las ceremonias oficiales ${ }^{35}$.

\section{LA AYUDA ECONÓMICA BRITÁNICA COMO FORMA DE "APACIGUAMIENTO"}

Además, los británicos, conscientes de la delicadísima situación económica a la que se enfrentaban tanto Tánger como el Marruecos español, ensayaron la misma política que estaban poniendo en práctica en la Península: ofrecer ayuda económica como medio de persuadir a España de que no entrase en la guerra. La política del "borrón y cuenta nueva" que en un principio los españoles pretendieron aplicar en Tánger demostró ser mucho más difícil de lo que habian pensado. De hecho y a pesar de haber sido integrada en la zona de Marruecos, las autoridades españolas se vieron obligadas a preservar el carácter especial de libertad comercial que venía disfrutando la ciudad, ante la imposibilidad de que supusiera una carga más para la desgraciada economía nacional. Tánger no producía absolutamente nada para el consumo interno, y muy poco para la exportación. Como gráficamente señalaba el cónsul británico, los únicos productos que se exportaban eran "unas toneladas de fibra vegetal y unas cuantas tortugas vivas» ${ }^{36}$. En época de paz, Tánger había dependido siempre de los suministros alimenticios procedentes del Marruecos francés, un territorio fértil y rico, tradicionalmente exportador, que suplía también de víveres al Marruecos español ${ }^{37}$. Tras la acción española en Tánger, las autoridades del Protectorado francés amenazaron con cortar

\footnotetext{
35 Mientras el representante diplomático norteamericano, al no reconocer su pais el hecho consumado de la ocupación, estuvo ausente de dichas ceremonias, no ocurrió lo mismo con su colega británico, empeñado en una deliberada tarea de limar asperezas y de mantener un trato amable. En cada entrevista con las autoridades de la zona, el cónsul, Gascoigne, reiteraba los deseos que animaban a su gobierno a prestar toda la ayuda posible a España, su interés en actuar en perfecta armonía con las autoridades españolas, etc.

36 Economic situation in the three zones of Morocco. 15 de agosto de 1941. PRO, FO $371 / 26927$.

37 El Marruecos francés no sólo producía alimentos y vino para la exportación sino también minerales, como fosfatos y cobalto. En tiempos de paz, España había importado del Marruecos francés unas 350.000 toneladas de fosfatos al año, que pagaba mediante exportaciones diversas a Francia.
} 
los suministros. España, por su parte, no tenía posibilidad alguna de proporcionar los productos básicos que se necesitaban.

Londres hizo todo lo posible por garantizar el abastecimiento de Tánger, así como del Marruecos español, autorizando exportaciones limitadas de productos básicos. Esta era la forma en que creía poder preservar la estabilidad del territorio, aplacar las ambiciones españolas sobre el Marruecos francés y, en definitiva, contribuir a una actitud antibelicista por parte de España ${ }^{38}$. Durante un tiempo, la principal vía de suministros siguió siendo la zona francesa de Marruecos pero, dadas las crecientes dificultades económicas de ésta, Tánger vivió cada vez más de las importaciones facilitadas por Gran Bretaña, no sólo británicas sino también portuguesas, norteamericanas y argentinas. En efecto, Gran Bretaña intercedió para que Portugal exportase a Tánger, y logró asimismo una mayor implicación de EE.UU. en esta parte de África, consiguiendo que mensualmente llegaran al enclave productos norteamericanos como harina y artículos manufacturados. Sin duda, la vida económica de Tánger durante los años de la guerra dependió básicamente de la ayuda aliada. El Foreign Office decidió que una vez al mes llegase al puerto de Tánger un barco con productos británicos de todo tipo (sobre todo textiles, jabón, té y azúcar), aunque lo cierto es que no pudo hacerlo con esa regularidad $y$, en realidad, la importancia cuantitativa del suministro británico fue pequeña en relación con su efecto propagandístico. A partir de 1942, la

Por mediación británica, España y el Marruecos francés firmaron en Madrid un acuerdo para que España pudiera recibir de la zona francesa los fosfatos que necesitaba urgentemente como fertilizantes para su maltrecha agricultura. A cambio de los fosfatos, España facilitaria a Marruecos azúcar y té, dos productos básicos en la economia doméstica de la población indigena, que a su vez le serian facilitados a España por Gran Bretaña, para cuya compra le concedia un amplio crédito. Gran Bretaña había impuesto al norte de Átrica francesa el bloqueo comercial desde el momento en que el General Noguès, comandante en jefe de los territorios franceses del norte de Átrica, decidió obedecer los términos del armisticio al producirse la caida de Francia y ser expulsados a continuación los representantes británicos en Argelia, Túnez y Marruecos. No obstante. poco después, decidió flexibilizar el bloqueo y permitir cierto tráfico controlado. Por razones politicas, intercedió para lograr llevar a cabo el acuerdo hispano-marroqui sobre fosfatos, facilitando su transporte hasta la Peninsula. De esta forma, Gran Bretaña esperaba contribuir a la estabilidad del norte de Africa, que tanto le interesaba, y creia tambien que se reducirian los deseos españoles de ocupar el Marruecos francés.

${ }_{38}$ El principal objetivo de la ayuda económica era reducir los deseos españoles de entrar en la guerra. No obstante, a partir de 1942, Gran Bretaña se benefició de su relación económica con España obteniendo también ciertas materias primas procedentes del Marruecos español. Por ejemplo, facilitó la maquinaria y el equipo eléctrico necesarios para mantener en explotación las minas del Rif y, a través de la Asociación Comercial del Reino Unido con sede en Tánger, consiguio que unas 600.000 toneladas de mineral de hierro fueran transportadas en barco desde Melilla a Inglaterra anualmente. Otras materias primas importantes para el ejército, como pieles y lana. fueron igualmente exportadas. 
aportación americana fue en ascenso. El cónsul británico aseguraba a este respecto:

“El control que mantuvimos sobre la economía española durante los dos primeros años de la guerra parece estar pasando - admito que necesariamente, dadas las circunstancias- a manos de los americanos» ${ }^{39}$.

Entre los artículos de primera necesidad que EE.UU. exportaba a Tánger y al Marruecos español había uno que las autoridades españolas apreciaban especialmente: la gasolina y otros derivados del petróleo. Las líneas áreas de la Compañía oficial «lberia» realizaban su servicio entre España y Marruecos con gasolina norteamericana ${ }^{40}$ y los camiones y autobuses también funcionaban gracias a ella.

Desde el principio los británicos fueron conscientes de que su principal baza, el arma económica, debía jugarse con extremada delicadeza y tacto, ya que si se esgrimía demasiado directa o explicitamente, corrian el riesgo de conseguir lo contrario de lo que se proponian dado el provervial carácter orgulloso de los españoles, que no aceptaba fácilmente el chantaje - la mediatización. La ecuación ayuda económica británica=neutralidad política española no podia establecerse con total claridad, al menos no a iniciativa británica.

A pesar de todos los esfuerzos aliados, la realidad fue, sin embargo, que Tánger estuvo por regla general desabastecida. La razón de la terrible escasez de víveres y otros productos básicos, y en general de la grave situación económica y financiera que vivía la ciudad al año de la ocupación no era, según el cónsul británico, consecuencia de la guerra sino de la gestión incompetente y corrupta de los nuevos administradores:

"Desde junio de 1940 en que los militares españoles ocuparon Tánger ha habido un constante y progresivo declive de la zona (...); a menos que se les haga ver a los españoles la gravedad de la situación, van a encontrarse en una posición de la que les resultará muy difícil salir. (...) pero no se ve qué

39 Gascoigne, 6 de agosto de 1942. PRO, FO, 371/31260.

40 EE.UU. también facilitaba combustible para el tráfico con las islas Canarias. Ante la sospecha de que los españoles pudieran estar acumulando reservas para pasarlas al enemigo, los americanos decidieron racionar los suministros ( 1.000 toneladas, al mes, $34 \%$ para usos militares) y, además vigilar mediante unos inspectores que no se acumulaban stocks. En cuanto al suministro de gasolina para Marruecos, en 1943 EE.UU. puso como condición que los nacionales de los países aliados viajaran gratuitamente en la linea "lberia" y que ésta no fuera utilizada por los enemigos de EE.UU. y de Gran Bretaña. Sin embargo, esta condición fue incumplida y en más de una ocasión individuos de nacionalidad alemana viajaron gratuitamente a África en "lberia». Véase, PRO, FO $371 / 31260$. 
puede hacerse si la administración española no se remodela sobre bases más eficientes y morales" ${ }^{41}$.

Los abusos que caracterizaban la vida española se habian trasladado también a Tánger, donde florecia un activo mercado negro ${ }^{42}$. Los funcionarios españoles, a cambio de una sustanciosa gratificación, permitían a los especuladores acaparar los alimentos esenciales para la población indígena -como la harina, el azúcar o el té-, al objeto de elevar los precios. Por su parte, la población marroquí, para poder comprar esos productos básicos, elevaban a su vez los precios de sus productos - huevos, pollos...-, e incluso se negaban a llevarlos al mercado, subsistiendo con ellos.

Pero, además, el desabastecimiento de Tánger se producia porque, en realidad, muy pocos de los productos que llegaban a la ciudad se vendian y consumian allí. Los que controlaban el comercio, que eran sobre todo los comerciantes judios, compraban los envios y los vendian al mejor postor. Atraídos por los elevados precios que podían conseguir en el Marruecos francés y español, reexportaban las mercancias a ambos territorios, contando por supuesto con la connivencia de las autoridades locales españolas. Durante muchos meses, fueron las propias autoridades militares españolas las que compraron y acapararon gran parte de las mercancías llegadas a Tánger, trasladándolas a la zona de Marruecos en grandes camiones. El Ministerio de Alimentación británico mostró su indignación ante la sospecha de que estos cargamentos pudieran estar siendo remitidos a Alemania, y sugirió que Tánger fuese sometida a un

41 Gascoigne a Mr. Eden, 20 de octubre de 1941. PRO, FO 371/26927.

42 En diciembre de 1941, las autoridades impusieron en Tánger, tanto para europeos como para marroquies, el sistema de racionamiento que funcionaba también en España y en el Marruecos español. Mientras tanto, en el mercado negro podian adquirirse todo tipo de productos a precios altisimos.

También en el Marruecos español la penuria y la corrupción eran generalizadas. El informante que los británicos tenían en Ceuta, un militar español que se ocultaba bajo el pseudónimo de "el marqués de Beramendi", daba cuenta en sus informes semanales de la desesperada situacion económica de la población: enormes colas en las tiendas, carencias de los productos más esenciales, crecientes suicidios de soldados que no podian soportar las privaciones y el hambre... Mientras tanto, las autoridades españolas falangistas tenian sus casas llenas de provisiones

Son muchas las menciones que los diplomáticos británicos de Tánger y Marruecos hacen sobre los funcionarios del protectorado enriquecidos con prácticas ilegales. Tomás Garcia Figueras era uno de los citados con más insistencia. En la relación de personalidades de Marruecos español que el cónsul británico en Tetuán enviaba a su gobierno decia expresamente: “es un hombre corrupto que ha sabido aprovecharse de su posición oficial para adquirir una considerable fortuna". PRO, FO, 371/31277. 
bloqueo total ${ }^{43}$. En el Foreign Office, sin embargo, restaron importancia al hipotético desvío hacia Alemania ${ }^{44}$. Más bien creían que las autoridades militares almacenaban las mercancías en previsión de tener que aguantar un bloqueo británico en caso de entrada de España en la guerra ${ }^{45}$. A los funcionarios británicos de Exteriores, en cualquier caso, no parecía preocuparles en exceso que parte de los suministros destinados a Tánger acabasen en el Marruecos español o francés, toda vez que Gran Bretaña y EE.UU. habian decidido hacer llegar también alimentos y productos básicos a estos territorios ${ }^{46}$. La aparición de artículos británicos en la zona francesa o española de Marruecos tenía un efecto propagandístico tan o más valioso que la llegada de productos de procedencia británica o americana a Tánger. Al Consulado británico en Tánger no le cabia ninguna duda de que la mejor propaganda que su gobierno podia hacer en este lado del Estrecho era facilitar la llegada de barcos cargados con suministros procedentes del Reino Unido:

43 Véanse los informes intercambiados entre los distintos ministerios implicados - Economic Warfare, Food, Department of Overseas Trade y Foreign Office- sobre los suministros a Tanger, en los meses de octubre, noviembre y diciembre de 1941. PRO, FO/371/26938.

Sabido es que hubo profundas divergencias entre los ministerios de Economia y el Foreign Office sobre el tema de los suministros y, en general, sobre el tema de la relajación del bloqueo en relación con territorios que, como España, la Francia de Vichy, o el África del norte francesa, estaban bajo influencia enemiga. El dilema era que, por una parte, habia que tratar de apaciguar a las autoridades de estos territorios para evitar que acabaran tomando parte activa del lado del Eje pero, por otra parte, habia que tratar de impedir que llegasen suministros a Alemania.

44 Los rumores sobre la posibilidad de que los productos enviados por los aliados fueran reexportados por los españoles a Alemania eran insistentes; de hecho, habia en la zona española de Marruecos agentes italianos y alemanes encargados de comprar suministros para el Eje; el cónsul británico en Tetuán, Mr. Moypenny, sólo daba crédito, sin embargo, a las noticias referidas al control, por parte de estos agentes, de la fábrica de conservas de pescado de Ceuta y al envio de las conservas a Alemania e Italia.

Véase, documentación referida a esta cuestión, en septiembre y octubre de 1941, en PRO, FO/ $371 / 26960$

4t El cónsul británico en Tánger tenia informes según los cuáles, en octubre de 1941, la oficina de intendencia de Tetuán tenia almacenadas harina, azúcar, aceite y otros alimentos equivalentes al suministro de seis meses.

4t: Por ejemplo, un acuerdo entre Washington y Vichy hizo posible que llegasen productos americanos, como petróleo y cereales, al Africa del norte francesa (Marruecos, Argelia, Túnez) con el compromiso, desde luego, de que no se reexportaran a los paises del Eje. No obstante, EE.UU. y Gran Bretaña eran conscientes de que gran cantidad de productos procedentes del Marruecos francés acababan en Francia e incluso en Alemania e Italia. Casablanca también era utilizada como puerto de liegada de mercancias (por ejemplo, caucho) procedentes de indochina y otras coIonias francesas que, desde alli, eran enviadas a Francia via Argelia. No cabe duda de que Alemania, a través de sus relaciones con Vichy, se benefició enormemente de las materias primas procedentes del Africa del norte francesa. Algunos informes hablan de que un $80 \%$ de las importaciones que llegaban a la Francia no ocupada acababan en manos del Eje. Véase, R.T. Thomas, Britain and Vichy. The Dilemma of Anglo-French Relations 1940-42. Londres, Macmillan, 1979, pág. 101 
"La repentina aparición de un barco con bandera británica es la mejor muestra de nuestra capacidad y determinación para ganar esta guerra".

«Debido al excelente efecto de los recientes suministros de té, hemos podido contrarrestar muy eficazmente la propaganda alemana, y es asi como los marroquies llegarán a asociar nuestra causa con el abastecimiento de alimentos, y la de España y su amiga Alemania con el hambre y las privaciones" 47 .

"El hecho de que Gran Bretaña, al tiempo que lucha por su supervivencia, sea capaz de exportar sus productos, y por consiguiente sea capaz de cumplir una función que resulta imposible para los países del Eje, causa aquí a todo el mundo una profunda impresión" ${ }^{48}$.

El Foreign Office luchó tenazmente contra los otros Ministerios implicados hasta conseguir que continuara el envío controlado de productos a Tánger porque era "el arma más efectiva para contrarrestar las actividades alemanas» ${ }^{49}$.

\section{LA POLITICA BRITÁNICA DE ATRACCIÓN DE LOS GENERALES ANTIFALANGISTAS}

Los británicos confiaron en lograr atraer a su causa a determinados Generales de relieve, rentabilizando sus rencillas con los falangistas, y en particular su enemistad hacia el pro-nazi Serrano Suñer. Con respecto al norte de África, la figura en la que pusieron todas sus esperanzas fue el general Orgaz, uno de los militares más relevantes y de mayor prestigio en España, que fue nombrado Alto Comisario en mayo de 1941 con bastantes más atribuciones que sus predecesores en el cargo ya que era, además, Comandante en Jefe de todas las fuerzas de la zona. Debido a recientes cambios en la administración del Protectorado, que habían suprimido el control del Ministerio de Asuntos Exteriores en favor de Presidencia del Gobierno, Orgaz era responsable tan sólo ante Franco. Al poco tiempo de su llegada, había impuesto un férreo control sobre todos los departamentos, no sólo en Tetuán sino también en Tánger - cuya dependencia administrativa con respecto a Tetuán era por entonces absoluta- rodeándose de personas de su total confianza ${ }^{50} \mathrm{y}$, en definitiva,

\footnotetext{
47 20 de octubre de 1941. PRO, FO 371/26927.

4. Annual Report. Tangier Zone, 1941. PRO, FO 371/31261.

ay Roger Makins, 10 de diciembre de 1941. PRO, FO/371/26938.

so En Tanger puso al general Uriarte como "delegado de la Alta Comisaria", y a Rafael Soriano como cónsul, es decir. como su consejero civil. El general Uriarte - decia el cónsul británico-se
} 
poniendo toda la autoridad de su carácter al servicio del fortalecimiento de su posición. Aunque no era popular debido a su temperamento autocrático, Orgaz logró ganarse el respeto de todos durante los casi tres años que ocupó el puesto en Tetuán. Además de la gran energía desplegada y de la estricta disciplina impuesta a sus subordinados, dio muestras de una gran independencia de carácter. No le gustaban las actividades de Falange, entre otras razones porque no queria ver ninguna autoridad que no fuera la suya en el territorio bajo su mando. Según el cónsul británico en Tánger, Orgaz era un general de casino, un militar conservador al viejo estilo ${ }^{51}$; sus simpatías no estaban ni con Gran Bretaña ni con Alemania sino con España; era "proespañol» y "antiextranjero"; aunque no tenía el más mínimo aprecio por los ideales democráticos, tampoco estaba dispuesto a aceptar fácilmente las imposiciones de los alemanes. Hoare decía de él que era un hombre tremendamente ambicioso, con grandes deseos de mando, y decidido a seguir los pasos de Espartero, Narváez y Serrano, que habian llevado a cabo con éxito golpes militares en el siglo XIX ${ }^{52}$. EI Foreign Office consideró que "su personalidad era uno de los factores decisivos al apreciar la situación en Marruecos" ${ }^{53}$. Su firme actuación dio pie a pensar que estaba decidido a desempeñar un gran papel, con independencia de Madrid si era preciso:

“Nuestra impresión - transmitia el Foreign Office a Washington en enero de 1942- es que el general Orgaz trata de desempeñar un papel independiente y que, si se le anima y se le ayuda, puede ser convencido para enfrentarse con medidas activas a una agresión alemana en el norte de África» ${ }^{54}$.

Tanto el embajador Hoare como el cónsul en Tánger, Gascoigne, contribuyeron a crear esta imagen de jefe con veleidades "separatistas" ${ }^{55}$. El cónsul habia podido percibir en su gestión «una clara tendencia a liberarse de los tentáculos de Madrid" imponiendo sus propios criterios; así pues, estaba convencido de que, si contaba con ayuda, estaría dispuesto

supone que debe actuar como la sombra de Orgaz. No es inteligente ni apto para las tareas politicas ni administrativas y no es particularmente amable con Gran Bretaña. (Véase, Personalities in Spanish Morroco and Tangier, PRO, FO, 371/31277).

51 Gascoigne a Foreign Office, 31 de mayo de 1941. PRO, FO 371/26960.

52 Hoare a FO. Madrid, 17 de julio de 1942. PRO, FO, 371/31240. Esto se lo habia dicho a Hoare el embajador portugués en Madrid, que era un amigo personal de Orgaz.

53 FO, 2 de noviembre de 1942. PRO, FO, 371/31277.

54 FO a Washington, 30 de enero de 1942. PRO, FO 71/31240.

55 Es curioso que, cada vez que se produce un atentado o un acto de discriminación contra los intereses británicos en Tánger, por lo demás bastante frecuentes, el cónsul británico tiende siempre a disculpar a Orgaz, suponiéndole no enterado de esas iniciativas. Pero ello se contradice con la idea de su poder absoluto y la insistencia de que Uriarte no es sino su sombra. 
a defender "Su» territorio de cualquier agresor que quisiera poner en él sus pies ${ }^{56}$. El Foreign Office creyó, pues, muy oportuno cultivar su amistad porque, si España llegaba a ser arrojada a la guerra, él podía «decidir actuar por su cuenta y capitanear un movimiento de resistencia anti-alemán en este lado del Estrecho" 57.

Pero los británicos iban a verse defraudados en sus expectativas. Para empezar, era un error creer que el Marruecos español podía recibir el mismo trato que el francés. El protectorado francés siempre había tenido un cierto grado de independencia de gestión en relación con la metrópoli, que se había acrecentado considerablemente tras el colapso de Francia en 1940 , lo que daba pie a tratar de llegar a acuerdos económicos o políticos por separado con las autoridades de Rabat. Sin embargo, en el caso del Marruecos español, el gobierno central, que no había sufrido ninguna pérdida de poder con la guerra, tenía sobre estos territorios un control absoluto. Cuando Washington inició negociaciones para un acuerdo económico con el Marruecos español quedó claro que Orgaz no tomaria iniciativa alguna sin contar con el beneplácito de Madrid ${ }^{58}$. Quizá era hostil al régimen de Franco, y sin duda aspiraba a reinstaurar en España la monarquía, pero era improbable y en cualquier caso impredecible que estuviese dispuesto a desoir las órdenes del Caudillo ${ }^{59}$. Ni británicos ni americanos lograron nunca de él un compromiso claro, concreto y preciso. Sólo dio vagas seguridades de que deseaba mantener la neutralidad en el norte de África. Por lo demás, fueran cuales fueran sus seguridades, los aliados tuvieron que acabar por reconocer que era imposible hacerse ilusiones de que las cumpliera; en definitiva, el General demostró no ser en absoluto fiable:

56 Véase, por ejemplo, Gascoigne a FO. 13 de enero de 1942. FO 371/31240.

57 Sobre la ayuda que Gran Bretaña está dispuesta a dar a Orgaz para que pudiera oponer. se a acciones del Eje en el norte de Átrica, véase, FO $71 / 31243$.

58 Un acuerdo para enviar suministros a la zona, señaló Orgaz al encargado de negocios de EE.UU., tendría que ser negociado en Madrid a través del Ministerio de Asuntos Exteriores. Véase, $\mathrm{PRO}, \mathrm{FO} / 371 / 31260$. Gascoigne reconocia al $\mathrm{FO}$ su desilusión dadas clas esperanzas que habiamos abrigado con respecto a sus supuestas tendencias separatistas" (6 de mayo de 1942. PRO, FO $371 / 31260$

59 Preston ha sugerido que Franco, que al parecer se ocupó muy esforzadamente por ganárselo, tuvo bastante que ver en la actitud remisa de Orgaz con respecto a los aliados. Según Preston, Franco tenía sobre la mesa de su despacho un dossier sobre las actividades ilicitas y corruptas de Orgaz en Marruecos. Véase, Franco, pág. 614. No obstante, sabemos a través de la documentación británica que el nombramiento de Orgaz como Alto Comisario, en mayo de 1941, vino a poner algo de orden en la corrupción y los desmanes existentes en relación con los aprovisionamientos de comida. Sustituyó a varios funcionarios sospechosos y el jefe de Falange de Ceuta, Emilio Pelegrina, ex-anarquista apodado "el carnicero de Ceuta", fue arrestado junto con sus colegas, acusado de acaparar provisiones y robar a la administración miles de pesetas. 
"Aunque Sir S. Hoare tiene sobre él una opinión favorable -aseguraba Roberts en el Foreign Office- a mi siempre me ha parecido que el General Orgaz ha colaborado con el Eje mucho más que la mayoria de los otros generales españoles, y eso a pesar de que hubiera sido para él más fácil no hacerlo, dada su posición en Marruecos» ${ }^{60}$.

"El general Orgaz - decía Williams - juega con todas las barajas a la vez, y no hace nada que justifique que podamos confiar en que haria lo apropiado en una crisis" 61 .

"Tenemos ciertas razones para dudar de los sentimientos del general Orgaz -aseguraban desde el Foreign Office a Washington en junio de 1942-; nos han llegado informes recientemente sobre la creciente cooperación entre los alemanes y las autoridades del Marruecos español y, a pesar de sus frecuentes protestas sobre su determinación a mantener la neutralidad de la zona, seria un error contar con que el General tomaria la decisión correcta en caso de ocurrir una crisis" 62 .

Evidentemente, la crisis a la que se referian era la que podía originarse como consecuencia del desembarco aliado en el norte de África que ya se proyectaba. Los aliados temían que los alemanes forzasen entonces a España a entrar en la guerra, o consiguiesen su permiso para atacar Gibraltar, en un último intento de cerrar el Estrecho.

El proceso de ilusión y desengaño de los británicos con respecto a personalidades políticas españolas fue bastante frecuente. Funcionarios civiles y militares que en un primer momento les habían parecido "razonables», «amigables», «juiciosos», etc., acabaron siendo descritos como "lobos con piel de oveja» o como personajes "resbaladizos como anguilas». En definitiva, acabaron llegando a la conclusión de que, si en un momento dado las relaciones eran buenas con cualquiera de estos personajes, podian sin embargo no serlo al minuto siguiente ${ }^{63}$. Por consiguiente, no cabía dar valor alguno a las garantías que pudiesen ofrecer.

60 Roberts. Comentario a un informe de Gascoigne sobre Orgaz de 8 de junio de 1942. PRO, FO, 371/31200.

61 Comentario al informe sobre la entrevista del agregado militar británico en Madrid, Brigadier Torr, con el Alto Comisario, 12 de junio de 1942. PRO, FO, 371/31277. Roberts escribe a continuación en el mismo informe: "Por to que a mi respecta, nunca crei que hubiera ninguna base sólida para abrigar ninguna confianza». Y, por último, Makins apunta: "Si, la embajada de Madrid siempre ha mostrado una confianza desmesurada con respecto a la actitud del General Orgaz. pero yo pienso que es muchisimo más implacable que la mayoria de los miembros de su entorno en Tetuán».

62 Foreign Office a Washington. 12 de junio de 1942. PRO, FO 371/31260.

6.3 El Ministro de Asuntos Exteriores hasta octubre de 1940, Juan Beigbeder, era uno de esos personajes cuya pretendida anglofilia suscitaba recelos en el Foreign Office. Cuando Beigbeder trató de que el gobierno britanico accediera a una ocupación española del Marruecos francés asegurando a Hoare que, de este modo, España quedaría completamente apartada de la guerra, el funcionario del departamento, Frank Roberts escribió: aNo puedo creer que España 
Una vez que se vio que la guerra seria larga y que quizás acabase en tablas, con una paz negociada, Orgaz se acostumbró, como el propio Franco, a hacer el juego a alemanes y británicos al mismo tiempo ${ }^{64}$. Gran Bretaña se benefició sin duda del desagrado e incluso de la indignación que la actitud prepotente y arrogante de los alemanes causaba en personas como Orgaz, que no soportaban la presión y mediatización de ningún pais extranjero. Para satisfacción británica, Noehring, el cónsul alemán en Tánger, resultó ser un exaltado nazi, inflamado con la causa nacionalsocialista de Hitler, que se comportó de forma brutalmente autoritaria con las autoridades españolas, lo que le granjeó la profunda antipatía de éstas y provocó finalmente su relevo en abril de 1942 cuando las relaciones habian llegado a ser francamente tirantes ${ }^{65}$. La conducta arrogante de los alemanes contribuyó a que Orgaz quisiese mostrarse amable con los británicos, y en varias ocasiones él y el resto de sus colegas aceptaron la invitación del Consulado general donde «mostraron una actitud en absoluto inamistosa hacia la causa aliada» ${ }^{66}$. Pero

esté simplemente esperando a obtener nuestra aquiescencia para lanzarse a una política que resultaria dificil de digerir por parte de Francia. Alemania o Italia. Si picamos el anzuelo que nos tiende el $\mathrm{Sr}$. Beigbeder, el resultado más probable seria que la noticia se transmitiría inmediatamente al gobierno francés, que se vería animado por consiguiente a adoptar una actitud más activa en contra de nosotros". Véase, Nota de Roberts de 24 de julio de 1940 en contestación a un telegrama de Hoare del día anterior. PRO, FO 371/24528. Paul Preston describe al Ministro como "el turbio y misterioso Beigbeder", calificativos que podrian hacerse extensivos a otros muchos militares considerados en principio anglófilos. Véase, Preston: Franco, "Caudillo de España", Barcelona, Grijalbo, 1994, pág. 454. En cualquier caso, ni Beigbeder, ni otros militares con cargos politicos, tenian la independencia de acción que los británicos hubiesen deseado sino que, por el contrario, cumplian las instrucciones que recibían de Franco.

64 Franco y su gobierno, incluido como vemos el Alto Comisario en Marruecos, jugaron un doble juego; por una parte, quisieron mostrar su vinculación al Eje dando amplias facilidades a los alemanes, que incluian el envio de alimentos y materias primas en una época de gravísima penuria económica en el país; $y$, por otra parte, se aprovecharon de la politica de apaciguamiento británica aceptando una ayuda económica que no les hacía sentirse comprometidos a permanecer fuera de la guerra.

Las peticiones de ayuda económica que España hizo a Alemania no sólo no fueron atendidas sino que, por el contrario. Hitler exigió la devolución de la deuda por la ayuda militar prestada en la guerra civil, y España se convirtió asi en suministradora de materias primas, sobre todo mineras, y también de mano de obra, de modo que tuvo una aportación nada desdeñable al esfuerzo de guerra alemán. Sobre las relaciones hispano-alemanas en este período y en concreto en su vertiente económica, es imprescindible la tesis doctoral de Rafael Garcia Pérez, Deuda, comercio y Nuevo Orden: España y el Tercer Reich durante la Segunda Guerra Mundial (1939-1945). Madrid, Univ. Complutense, 1992. Véase un resumen del mismo autor, "Franquismo y Tercer Reich: la vertiente económica del Nuevo Orden", en W.L. Bernecker (ed.): España y Alemania en la Edad contemporánea. Vervuert, 1992.

65 Véase, por ejemplo, encargado de negocios americano en Tánger a Departamento de Estado. 2 de junio de 1942. PRO, FO 371/31260. Al parecer, las relaciones con su sustituto, Kurt Reich, fueron bastante mejores.

66 Véase, por ejemplo, Gascoige a Eden. Tánger, 16 de julio de 1942. FO, 371/31240. 
definir a Orgaz como "proaliado" parece bastante inexacto. En 1943, cuando los triunfos favorecían a los aliados, estrechó sus relaciones con los alemanes y Gascoigne tuvo que señalar descorazonado que el Alto Comisario se volvía "cada vez más despótico y violentamente irracional» hacia Gran Bretaña.

Quizá no sea pertinente preguntarse si la postura tan escrupulosamente contemporizadora de los británicos hacia España fue efectiva. Lo cierto es que esta política "de vaselina" no fue compartida por todo el gobierno inglés y no fue entendida desde luego por la colonia británica de Tánger, que reclamó mayor dureza en el trato con las autoridades españolas. Es verdad que, por lo que se refiere específicamente a los intereses británicos en Tánger, a cambio de la ayuda económica —créditos, envio de suministros, facilidades de transporte de mercancías, etc. - Gran Bretaña obtuvo un importante triunfo al arrancar a los españoles la firma de un acuerdo gracias al cual, durante los años de la ocupación española, pudo seguir manteniendo en Tánger la posición de la que había disfrutado previamente. El acuerdo garantizaba la plena libertad de movimientos de los súbditos británicos y la inviolabilidad de sus domicilios; permitía la libre entrada y salida del puerto de los buques mercantes británicos, así como el libre funcionamiento de las instituciones británicas (hospital, oficina de correos, sociedades deportivas, etc.) ${ }^{67}$. Pero muchos de los británicos que trataban a diario con las autoridades españolas estaban convencidos de que "doblar sistemáticamente la cerviz" y no contestar a las provocaciones les hacía débiles, inertes y despreciables a los ojos de las autoridades españolas, que tanto valoraban en cambio la diplomacia viril y aguerrida de los alemanes. "La firmeza y la contundencia —decía un residente británico en 1943- es el único lenguaje que la gente de Franco entiende y, dicho sea de paso, admira" ${ }^{68}$. "Los españoles nos miran hoy con indiferencia rayana en el desprecio", afirmaba por su parte el agregado de prensa del Consulado.

\section{TÁNGER TRAS EL DESEMBARCO ALIADO EN EL NORTE DE ÁFRICA}

En Tánger, la consecuencia más clara e inmediata del desembarco aliado en el norte de África ( 8 de noviembre de 1942) fue que la influencia

67 Por lo demás, el gobierno español se comprometía a indemnizar a los funcionarios británicos que habian sido expulsados de forma expeditiva. El acuerdo o modus vivendi fue suscrito en Madrid por el embajador británico, Samuel Hoare, y el Ministro español de Asuntos Exteriores, Serrano Suñer, el 1 de enero de 1941. Sin duda fue un arma valiosisima esgrimida en reiteradas ocasiones para impedir la violación de los derechos de la comunidad británica

68 Recopilación de comentarios de residentes británicos sobre la administración española de Tánger. 18 de enero de 1943. PRO, FO $371 / 34779$. 
alemana sobre las autoridades locales españolas aumentó de forma considerable. Desalojados del Marruecos francés y de Argelia, los agentes que hasta entonces operaban en aquella zona se desplazaron al área norteafricana controlada por España, que durante un tiempo se convirtió en un auténtico nido de espias nazis. Los intereses británicos en Tánger sufrieron por entonces un acoso sin precedentes. Las autoridades españolas trataron de modificar el acuerdo hispano-británico asegurando que los privilegios de la población inglesa, autorizada por ejemplo a entrar y salir de Tánger sin necesidad de obtener un salvoconducto español, era discriminatoria hacia los súbditos de Alemania ${ }^{69}$. Las autoridades españolas estaban de un humor terrible ante el avance aliado en un territorio tan próximo y tan codiciado ${ }^{70}$. No puede olvidarse, en efecto, que se trataba de la región que los españoles habian ansiado anexionarse. Temeroso de una invasión aliada del Marruecos español, Orgaz desató una persecución de todos aquellos sospechosos de simpatizar con los aliados ${ }^{71}$. En la zona de Marruecos el trato a los aliados empeoró aún más ${ }^{72}$. El cónsul británico se atrevió por primera vez desde la ocupación española a actuar con cierta firmeza. Como protesta ante la brutalidad y arbitrariedad con que Orgaz mandó reprimir las muestras de alegría de parte de la población ante las victorias de las democracias, rechazó la invitación para asistir a una ceremonia oficial

69 También pretendieron suprimir la edición francesa y española de la Tangier Gazette considerando que todo lo que no se editase en inglés era propaganda, y por tanto violaba la neutralidad de la zona.

70 "Los españoles muestran un orgullo quijotesco al adoptar una actitud cada vez más antialiada y pro-alemana" (Vease, Annual Report, 1943).

71 Cientos de simpatizantes de los aliados fueron en aquellos dias arrestados en masa y conducidos a prisiones en Ceuta o Tetuán. Jóvenes marroquies, mayoritariamente judios, fueron llevados a campos de concentración con acusaciones falsas de haberse alistado en las fuerzas francesas para combatir a los alemanes y haber violado así la neutralidad de Tánger. Entre los "españoles rojos" hubo más de 250 detenidos acusados de «comunistas" y "espias al servicio de Gran Bretaña".

El representante en Melilla no dudaba en afirmar por aquellos dias que estaba viviendo "en territorio enemigo", sometido él, su familia y sus subordinados a una vigilancia constante, "ninguneado" mientras los representantes del Eje eran tratados de la forma más amistosa, y en fin, sometido a una agobiante atmósfera de antagonismo que le resultaba dificil de sobrellevar. Ninguna persona que no tuviera una diligencia precisa y concreta que tratar en el viceconsulado era autorizada a ir alli bajo pena de arresto. El vicecónsul describia la atmósfera que se respiraba en Melilla como "un reino del terror" en el que los numerosos falangistas y elementos de extrema derecha dominaban la situación. Como ejemplo, daba cuenta de las atrocidades que, aún después de la guerra civil, seguian cometiéndose en la plaza: «Los falangistas de vez en cuando reclamaban al gobernador de la prisión un grupo de prisioneros que, sin ningún tipo de juicio, eran ejecutados durante las horas de la noche por personas sin ninguna autoridad real más que figurar como miembros influyentes del partido de Falange. Hasta 32 cadáveres fueron encontrados tendidos en una carretera cercana a Melilla tras una de estas vengativas matanzas". Véase, Mr. Gore-Edwards a Gascoigne, 8 de diciembre de 1942. PRO, FO $371 / 34779$. 
española presidida por el Alto Comisario, el cual, no acostumbrado a semejantes desplantes, montó en cólera. No obstante, el cónsul aseguraba a su gobierno que la medida, en sí misma insignificante, había tenido un efecto de lo más "saludable" sobre las autoridades españolas, que no sólo no habían tomado contra el Consulado británico ninguna medida de represalia sino que, por el contrario, habían suavizado su actuación antialiada ${ }^{73}$.

Comprobado el efecto sedante de una reacción británica más fuerte de lo habitual, el gobierno británico se negó a renunciar a ninguno de sus derechos en Tánger, recordando que Gran Bretaña no gozaba de ningún privilegio que no disfrutase previamente con el régimen internacional. Su posición se derivaba de su participación en todos los tratados sobre Marruecos, y en concreto en las negociaciones tangerinas de 1923 y 1928. En cambio, la posición de Alemania era jurídicamente inexistente. Por tanto, la reclamación de igualdad por parte de Alemania no tenía ninguna base legal ${ }^{74}$. El gobierno británico dejó claro, además, que la ocupación española habia sido un acto ilegal, igual que todas las medidas tomadas desde entonces por los españoles, y señaló una serie de actividades de los agentes de los servicios secretos alemanes que demostraban que el Eje violaba la supuesta "estricta neutralidad" tangerina.

Los diplomáticos británicos de Tánger creían que, tras el desembarco aliado en el norte de África, había llegado el momento de "acometer la tarea de recuperar algo de nuestra dignidad perdida». Gascoigne, que tantas veces habia sido tachado de blando y débil por la colonia británica, creía que era ya hora de reaccionar y de mostrarse más duros, para empezar a ganarse el respeto de los españoles y «porque continuar con la política de ayudar y aplacar a España puede superar los límites de dignidad de una gran potencia". La soberbia española era, ahora que los éxitos en el campo de batalla sonreían a los aliados, más difícil de tragar:

«El gobierno español sufre en el presente un complejo de superioridad. Ha sido tan enormemente cortejado por ambos bandos en estos últimos tres años que ha llegado a convencerse de que España es una potencia de primer orden a la que el mundo debe escuchar».

73 Por ejemplo, los jóvenes enviados a campos de concentración habian sido liberados, y desde entonces no habian vuelto a producirse nuevas persecuciones a gran escala.

74 Muy al contrario, la existencia de una representación oficial alemana era ilegal según los términos del Estatuto tangerino vigente en el momento de la ocupación española. Más aún, todos los sujetos alemanes llegados a Tánger desde la ocupación estaban alli ilegalmente ya que ninguno de ellos había cumplido el requisito estipulado por la ley de 1933 según la cual todo alemán que quisiera ir a Tánger debía obtener previamente el permiso del Sultán a través de su ministro de Asuntos Exteriores que era el Residente general frances en Rabat. 
Pero las peticiones del Consulado de iniciar una política de represalias ante la ensoberbecida actitud española, que había acelerado el ritmo de sus ilegalidades en Tánger, no fueron atendidas de momento. Ante las demandas de Gascoigne, en el Foreign Office Roberts señaló:

"La situación es claramente insastisfactoria y no la debemos consentir indefinidamente, pero es mejor que no apretemos las clavijas a los españoles hasta que no hayamos limpiado el norte de África» ${ }^{75}$.

El Foreign Office no se atrevió a modificar su política "acomodaticia» hasta que el Eje no fue totalmente expulsado del norte de África, en junio de 1943. Una vez que los británicos se sintieron ya seguros en el norte de África, comenzaron a tomar alguna medida un poco más contundente, como solicitar la expulsión de los funcionarios, agentes y demás individuos de nacionalidad alemana sobre la base de que su presencia en Tánger era contraria a los tratados que existían cuando la ciudad era internacional ${ }^{76}$.

\section{EL FUTURO DE TÁNGER}

Ante la pertinaz timidez del Foreign Office en su trato con las autoridades españolas de Tánger, la colonia británica mostró su temor a que se consintiese que, tras la guerra, España siguiese en posesión de la zona. Desde el desembarco, los españoles estaban haciendo un desesperado intento de agilizar la hispanización de la ciudad, acometiendo algunas tareas que aún quedaban por hacer para dar una apariencia totalmente española a la ciudad ${ }^{77}$. Desde la óptica británica, el balance de la ocupación española no podía ser más negativo ${ }^{78}$. Según el cónsul, en 1940 los

75 Comentario de Roberts a un informe de Gascoigne de 20 de enero de 1943. PRO, $\mathrm{FO} / 371 / 34779$.

36 Véase, Carlos Collado Seidel: “España y los agentes alemanes. 1944-1947. Intransigencia y pragmatismo político", en Espacio, Tiempo y Forma, t. V, 1992, págs. 431-482.

${ }_{77}$ Se cambiaron los nombres franceses de las calles por otros españoles, y por ejemplo, la calle principal que antes se llamaba "Rue du Statut" pasó a llamarse "calle de Su Alteza Imperial el Jalifa". No obstante, según los residentes británicos, el esfuerzo y dinero empleados no habian servido de nada porque nadie parecia darse por aludido y todo el mundo seguia llamando a las calles por su nombre de siempre.

${ }_{78}$ Muy diferente, desde luego, al punto de vista del régimen franquista, para quien la gestión española en Tánger durante los años de la guerra mundial fue modélica. Véase, Tánger bajo la acción protectora de España durante la Segunda Guerra Mundial, Madrid. Ministerio de Asuntos Exteriores, 1946. Sobre el balance británico de la administración española, véase, Tangier under the Spanish Administration. PRO, FO 371/34727. 
residentes de Tánger habian abrigado grandes temores dada la reputación de España de llevar miseria, desorden y hambre a donde quiera que fuese, temores que en los años siguientes se habían cumplido totalmente.

La vida se habia encarecido enormemente, lo que había sumido a la población indígena en una situación de privaciones y hambre, y habia causado grandes trastornos a la población europea, que también sufría la tremenda subida de los precios. El turismo había cesado por completo y los acaudalados residentes europeos que no se habian marchado estaban perdiendo gran parte de su dinero.

La carestía y la escasez de productos habian creado un problema crónico de inseguridad ciudadana. Proliferaban las bandas de asaltadores que robaban en casas, calles y mercados. A pesar de que habían aumentado considerablemente los efectivos de policia de todo tipo, su ineficacia era la tónica habitual ${ }^{79}$. Había quienes estaban convencidos de que los marroquies se dedicaban a esta tarea con la connivencia de las fuerzas de policía españolas, que luego compartían el botín obtenido.

Los españoles habian aumentado los impuestos y las tasas de aduana muy por encima de lo permitido por los tratados en vigor antes de la ocupación. Además, habian introducido otros impuestos nuevos, copiados de la zona española de Marruecos ${ }^{80}$. La excusa era que las nuevas cargas fiscales estaban destinadas a "beneficios sociales" y "fines caritativos", pero no se habia producido ninguna mejora en beneficio de la población, ni emprendido ningún tipo de obra pública. Al cabo de tres años de ocupación, el aspecto general de la ciudad era de deterioro y abandono ya que no se habia acometido ningún trabajo de reparación en las calles y edificios de la ciudad. El dinero obtenido con el incremento de los impuestos, que en teoría debía destinarse a obras sociales, se dedicó en buena parte a la compra de propiedades para aumentar la presencia de «intereses españoles» en la zona. Además, en el transcurso de 1943 se

\footnotetext{
Fueron muy trecuentes las quejas de subditos británicos ante su Consulado por la indolencia y pasividad de la policía, que sólo parecia dispuesta a tomarse alguna molestia si recibia una generosa propina. Véase, dossier sobre comentarios de residentes británicos sobre la administración española de Tánger, 19 de noviembre de 1942. PRO, FO 371/34779. El uniforme de la nueva policía española - gris azulado con trebillas verdes («mitad alemán, mitad italiano"), casco. cinturón y enormes guantes blancos, causaba hilaridad a los residentes británicos: "¡hay que verlo para creerlo!", aseguraba uno de ellos.

80 Además, las tasas e impuestos debían ser pagados en pesetas y no en francos marroquies. que era la otra moneda de curso legal en Tánger. Hubo por tanto una gran demanda de pesetas pero puesto que, según las regulaciones monetarias españolas, no se podian importar legalmente pesetas desde España o el Marruecos español, hubo una constante carencia de esta moneda que. por consiguiente. estuvo artificialmente sobrevalorada.
} 
incrementaron las tareas de fortificación de Tánger y se llevaron más tropas y artillería. Lo que estaba claro era que, ante la incertidumbre sobre el resultado final de la guerra, los españoles estaban empeñados en poder decir "aquí estamos y aquí nos quedamos".

En el Consulado británico creian que si los aliados no consideraban oportuno ocupar Tánger antes del final de la guerra, había que hacerlo inmediatamente después. Lo que en cualquier caso debía evitarse a toda costa era que los españoles siguieran controlando la zona en el período que transcurriese entre el armisticio y el momento en que las potencias decidiesen abordar el tema tangerino. Teniendo en cuenta los problemas de primera magnitud que habría que tratar, ese período podía llegar a ser demasiado largo.

Los británicos tangerinos se mostraron unánimemente contrarios a reinstalar el régimen internacional por considerarlo impracticable debido a las rencillas entre las distintas nacionalidades, que habían sido la tónica habitual antes de $1940^{81}$. La solución propuesta por el cónsul era que Gran Bretaña - o quizá Gran Bretaña y EE.UU. conjuntamente en régimen de condominio - tuviese el control no sólo de Tánger sino de una parte del Marruecos español para garantizar sin trabas la libertad del Estrecho. Un territorio que diese adecuada protección aérea y terrestre a los barcos que cruzasen el Estrecho y protegiese asimismo Gibraltar.

Sin embargo, en las altas esferas, con una visión global del problema, pareció más sensato no hacer grandes cambios con respecto a la situación prebélica en esta parte de África. No podia olvidarse que Gran Bretaña se había comprometido a restablecer la grandeza de Francia, también en su dimensión colonial. Además, sería necesaria en la Europa de posguerra una "España amigable" lo que no sería posible si se le privaba de su única "reliquia imperial». De ahí que, en 1945, se restableciese el régimen internacional en Tánger pero España continuase en posesión de su zona de Marruecos.

\footnotetext{
81 Este era. por ejemplo, el criterio del británico que habia sido vicepresidente de la Asamblea Legislativa de Tánger durante quince años. También el cónsul, Gascoigne, creia que la fórmula del régimen internacional debia evitarse porque "según mi experiencia, ha demostrado ser un tructífero campo de cultivo de agrias disputas internacionales que no sólo afectan a la situacion local sino que tienen también repercusiones en las relaciones generales entre los gobiernos de los paises implicados (26 de junio de 1943. PRO, FO, 371/34726). Desde luego, el régimen internacional no habia funcionado a la perfeccion, debido fundamentalmente a las innumerables fricciones entre Francia y España.
} 